\title{
Addition of juvenile oysters fails to enhance oyster reef development in Pamlico Sound
}

\author{
Nathan R. Geraldi ${ }^{1,3,}$, Michael Simpson ${ }^{1}$, Stephen R. Fegley ${ }^{1}$, Pelle Holmlund ${ }^{2}$, \\ Charles H. Peterson ${ }^{1}$
}

${ }^{1}$ Department of Marine Sciences, University of North Carolina at Chapel Hill, Institute of Marine Sciences, Morehead City, North Carolina 28557, USA

${ }^{2}$ North Carolina Division of Marine Fisheries, Morehead City, North Carolina 28557, USA

${ }^{3}$ Present address: Beaufort Laboratory, Southeast Fisheries Science Center, National Marine Fisheries Service, Beaufort, North Carolina 28516, USA

\begin{abstract}
Oyster reefs are one of the most depleted and degraded marine habitats worldwide. To reverse the current oyster reef declines, governmental and private organizations have invested substantial resources into oyster restoration. Restoration primarily consists of deploying hard substrate. If oyster recruitment is thought to be limited, hatchery-raised juvenile oysters are set on the hard substrate. These costly setting efforts are carried out despite limited information on whether seed oysters accelerate reef development and, if so, how oyster size and time of deployment maximize oyster survival. North Carolina, USA, has established subtidal oyster sanctuaries in Pamlico Sound using marl mounds and hatchery-raised juvenile oysters set on recycled shell. We experimentally manipulated marl mounds at 3 sanctuaries differing abiotically and biotically during summer 2010 and varied recycled shell and seed presence, seed size, and shell and seed deployment date. Although oyster settlement varied spatially, natural recruitment swamped any measurable effect of seeding. Our findings, in combination with information from 3 additional sanctuaries seeded in 2006 and 2008, indicate that seeding does not enhance oyster reef restoration efforts in Pamlico Sound. Financial resources used for oyster seed would be better used to increase the amount of substrate for oyster settlement. Although our results may not apply to areas with less natural oyster recruitment, our study highlights the need to quantify basic ecological processes on appropriate spatiotemporal scales to optimize restoration actions. Analogous information should underlie restoration planning for other biogenic habitats like seagrass meadows and coral reefs.
\end{abstract}

KEY WORDS: Conservation - Crassostrea virginica - Biogenic $\cdot$ Bivalve $\cdot$ Habitat $\cdot$ Sanctuary Shellfish

\section{INTRODUCTION}

The extent of historic loss and degradation of biogenic marine habitats caused by humans is staggering (Lotze et al. 2006). Although remaining threatened habitats may be maintained through conservation efforts, habitat restoration will be needed to regain lost habitat and associated ecosystem services. Resto- ration ecology may become one of the most important scientific endeavors of this century (Hobbs \& Harris 2001) and is an essential component of conservation and management (Hobbs et al. 2011). To maximize the benefits of how limited resources for restoration are used, restoration techniques must be based on rigorous ecological experimentation (Blankenship \& Leber 1995). 
Eastern oyster Crassostrea virginica populations have been a target of decades of restoration efforts (Brumbaugh \& Coen 2009, Kennedy et al. 2011) because only $15 \%$ of historic oyster populations persist worldwide (Beck et al. 2011). Unlike other marine biogenic habitats such as seagrass meadows or coral reefs, oysters are harvested for human consumption, thus increasing risk of degradation and decline. In addition to supporting a bivalve fishery, oyster reefs also provide other ecosystem services including enhanced production of fishes, crabs, and shrimps (Lenihan et al. 2001, Peterson et al. 2003) and improved water quality through filtration and denitrification (Coen et al. 2007, Grabowski \& Peterson 2007 , Piehler \& Smyth 2011). The economic value of ecosystem services provided by non-harvested reefs is greater than the value of oysters obtained from harvesting the reefs (Peterson et al. 2003, Coen et al. 2007, Grabowski \& Peterson 2007).

To restore the services provided by lost oyster reefs, governmental and private organizations have invested substantial resources into oyster restoration, but the knowledge necessary to maximize the effectiveness of restoration is limited. Restoration efforts include providing hard substrate for oysters to grow on such as oyster shell, clam shell, or marl rip-rap (Soniat et al. 1991, Coen \& Luckenbach 2000, Mann \& Powell 2007, Brumbaugh \& Coen 2009). Where oyster recruitment is thought to limit oyster reef creation, the new reefs may be seeded with juvenile oysters. We will refer to oyster recruitment as the number of oysters that settle and survive to a size that can be visually sampled $(\sim 5 \mathrm{~mm}$ shell height, $\mathrm{SH}$ ). Seeding consists of spawning oysters in captivity, allowing the larvae to settle on recycled shell, raising the juvenile oysters in captivity to a size at which it is thought mortality from predation is reduced, and then deploying the seeded shells on natural substrate or onto constructed reefs. This practice occurs over the entire range of the eastern oyster (see review by Brumbaugh \& Coen 2009) including New Hampshire (Grizzle et al. 2006), Virginia (Associated Press 2007), Maryland (Rodney \& Paynter 2006), Alabama (Wallace et al. 2002), and North Carolina (NC). NC has devoted public resources to building multiple oyster hatcheries (\$4.3 million in 2008) and deploying seeded shells on harvested areas (Ortega \& Sutherland 1992) and oyster sanctuaries. The use of seeded reefs is necessary in areas of negligible recruitment (Rodney \& Paynter 2006). Remarkably, even though oyster seeding is a costly and widespread restoration practice, there are no tests of the efficacy of seeding in enhancing oyster populations where recruitment occurs but is thought to limit restoration success.

Oyster recruitment may limit restoration success because adult oysters could be locally extinct or so depleted that larval supply is low and settlement onto hard substrate does not occur in densities that result in sufficient recruitment to develop an oyster reef. If settlement is limiting reef restoration, a network of reefs may need to be restored to ensure sufficient larval supply to maintain oyster populations, because oysters have a 2 to 3 wk pelagic larval stage (Kennedy et al. 1996) and usually do not recruit to the same reef on which they were spawned. However, it is difficult to determine whether settlement is limiting recruitment, because settlement varies in space and time (Michener \& Kenny 1991, Ortega \& Sutherland 1992, Austin et al. 1996). An area that is settlement-limited one year may not be the next. Devoting resources to deploy seed oysters to create functional oyster reefs may or may not be necessary for oyster reef restoration depending on oyster settlement and subsequent recruitment in space and time.

In addition to bottom-up factors limiting recruitment, post-settlement mortality can also make seeding necessary to restore oyster reefs. High oyster mortality from predation could result in few oysters reaching maturity (Wallace et al. 2002, Kraeuter et al. 2003). Shellfish seed survival varies strongly with seed size and date of deployment (Peterson et al. 1995), and predation risk and oyster size are negatively correlated (Newell et al. 2000, Kulp et al. 2011). Predation can vary in time as predators migrate with season (Brown et al. 2008), recruit to oyster reefs and grow to sizes that consume oysters (McDonald 1982), or are indirectly affected by higher trophic levels (Abbe \& Breitburg 1992, Grabowski 2004). Oyster mortality also varies spatially because of physiological constraints of oyster predators (Wallace et al. 2002). Knowledge of how seed survival is affected by size at deployment, date of deployment, location of deployment, and the interaction of these factors is necessary to maximize resources invested in seed production (Peterson et al. 1995).

We tested the effect of adding seeded recycled shell onto marl mounds in 3 different oyster sanctuaries in Pamlico Sound, NC. Oyster recruitment in Pamlico Sound occurs from May through October (Ortega \& Sutherland 1992). Recruitment can be continuous or have multiple peaks, with the highest recruitment in August and September. Recycled oyster shell and recycled oyster shell with small seed oysters attached were deployed in early summer, and 
shells with 2 sizes of seed oysters (small and large) were deployed in mid-summer. Deployed shell and mound surface (marl) were monitored to determine the effect of seeding on oyster abundance and reef development (abundance and size of oysters on deployed shell and oyster density on the surface of the marl boulders of different treatments over time). To expand our empirical findings in both space and time, we analyzed survey data from the North Carolina Division of Marine Fisheries (NCDMF) from 3 additional sanctuaries seeded in 2 different years. The goal of our study was to guide future restoration efforts so that the limited resources devoted to oyster reef restoration can be maximized by determining if seed oysters are necessary for oyster restoration and, if so, when and at what size the seed oysters should be deployed to minimize seed mortality.

\section{MATERIALS AND METHODS}

\section{Reef creation and seeding procedure}

To test how 3 combinations of seed size and planting date, plus substrate type (recycled shell and marl), influence the success of oyster reef development as a function of location, this experiment was repeated at 3 NCDMF oyster sanctuaries in Pamlico Sound, NC (Clam Shoal, Crab Hole, and Gibbs Shoal; Fig. 1A). Oyster harvest is illegal within the 11 oyster sanctuaries in Pamlico Sound. We choose the 3 sanctuaries because they span the wide range of salinities that exist in Pamlico Sound and because they contained newly created mounds (constructed after December 2009). Each oyster sanctuary consisted of 50 to 300 mounds of rip-rap marl rock. The marl pieces were approximately the size of volleyballs. Each mound contained $150 \mathrm{t}$ of marl elevated $3 \mathrm{~m}$ high with a footprint diameter of $15 \mathrm{~m}$. Mounds were created in a uniform grid, with mounds separated by $\sim 25 \mathrm{~m}$ (Fig. 1B). Mean water depths at Clam Shoal, Crab Hole, and Gibbs Shoal were 3.4, 4.0, and $4.3 \mathrm{~m}$, respectively.

Larvae, spawned from 15 oysters collected from the West Bluff oyster sanctuary in Pamlico Sound, were purchased from Middle Peninsula Aquaculture in Foster, Virginia. Substrate for seeding consisted of harvested oysters with $>7.2 \mathrm{~cm}$ SH from the NCDMF recycling program; the oysters were thoroughly cleaned by repeated dunking in seawater and then moved to completely fill 701 plastic crates ( 2 bushels; $2.5 \mathrm{~cm}^{2}$ openings separated by $1 \mathrm{~cm}$ thick plastic on sides and bottom, with open tops). Eighteen crates

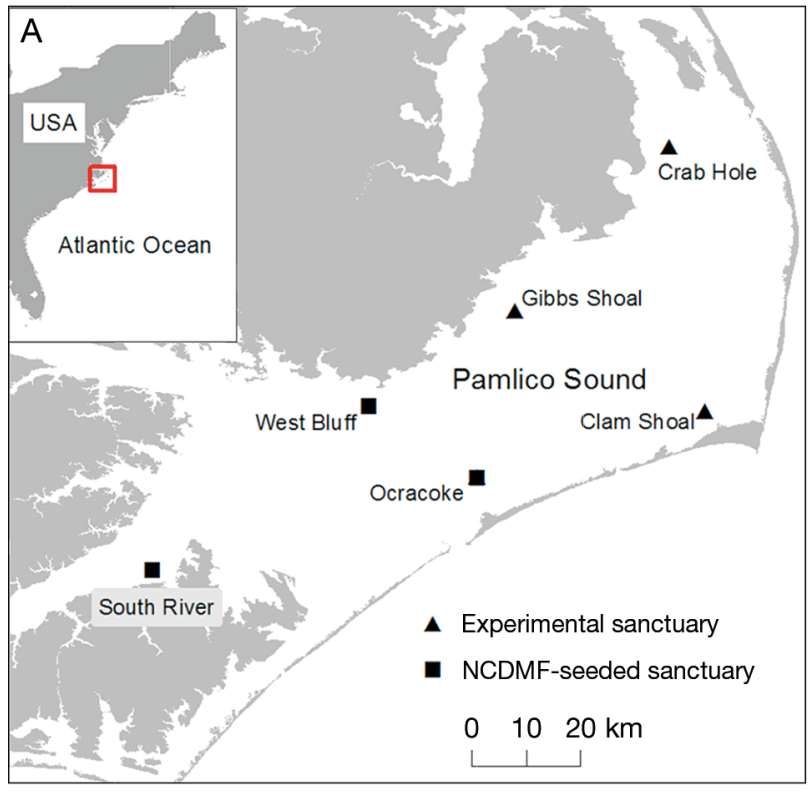

B

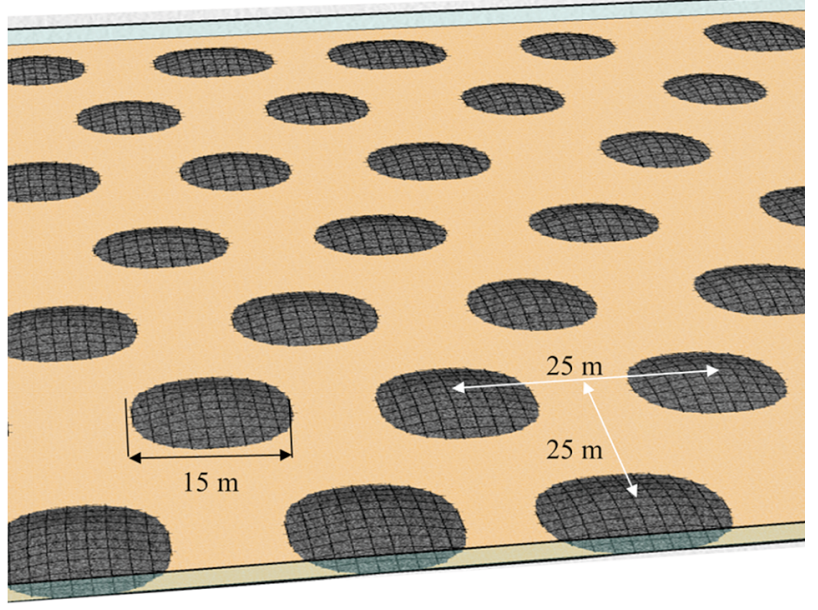

Fig. 1. (A) Sampled oyster sanctuaries in Pamlico Sound and (B) layout of marl mounds within sanctuaries. Experimental sanctuaries had 5 shell/seed treatments. North Carolina Division of Marine Fisheries (NCDMF) seeded sanctuaries had either seeded or unseeded mounds and were sampled by NCDMF

were placed into 6 tanks $(4.9 \times 0.9 \times 0.8 \mathrm{~m})$ located on the NCDMF dock in Morehead City, NC, filled with unfiltered seawater from Bogue Sound. Approximately 2.5 million eyed larvae were added to each tank and fed plankton provided by Middle Peninsula Aquaculture twice a day. The larvae were given $3 \mathrm{~d}$ to settle, after which time unfiltered seawater was pumped (4.4 $\mathrm{l} \mathrm{s}^{-1}$ for each tank) directly from Bogue Sound until the seeded shells were deployed on reefs. Salinity was measured weekly at the NCDMF dock using a SonTec/YSI instrument and ranged 
from 21 to 31 psu. One to 3 d before deployment, crates were divided into 9 sections $(3 \times 3$ grid when viewing the broad side of the crate), and 1 to 3 shells were haphazardly chosen from each section to ensure that the 9 shells were sampled evenly throughout the crate. Seed oyster abundance and size were determined by counting the number of juvenile oysters per shell and measuring the height of 5 haphazardly chosen spat on each shell.

Larvae were set on shell in 2 independent additions of eyed larvae, on May 25 and July 5, 2010. Large seed oysters were produced on half the seeded shells from the May addition, and these shells were kept in separate tanks until the second addition. We ran 5 treatments: (1) recycled shell deployed in late June 2010, (2) small seed oysters set on recycled shell ( $~ 5 \mathrm{~mm} \mathrm{SH}$ ) deployed in late June 2010, (3) small seed oysters set on recycled shell ( 2 mm $\mathrm{SH})$ deployed in mid-August 2010, (4) large seed oysters set on recycled shell ( 10 $\mathrm{mm} \mathrm{SH})$ deployed in midAugust 2010, and (5) no shell addition (marl). These treatments will be referred to as early shell, early small seed, late small seed, late large seed, and marl only, respectively. At each sanctuary 10 mounds were haphazardly assigned 1 of 5 treatments for a total of 2 mounds per treatment (2 replicates per treatment per sanctuary). Mounds with shell treatments received 5601 of shells (seeded or unseeded depending on the treatment), which were deployed on the top of the mounds. The early deployment was achieved by transferring the oyster-filled tanks into a dump truck and transporting them from Morehead City to boat launches near the sanctuaries, where they were then delivered to the mounds by boat. Transport in the tanks took $<5 \mathrm{~h}$. Seed and shell were deployed at Crab Hole, Gibbs Shoal, and Clam Shoal on June 21, 22, and 23, respectively. For the second deployment, oyster tanks were transported from their original location on the NCDMF dock to the sanctuaries by barge. Oysters remained in the tanks on the barge deck with a continuous supply of unfiltered seawater for $\sim 10,20$, and $24 \mathrm{~h}$ as shells were deployed sequentially in the 3 sanctuaries. Seeded shell was deployed in Clam Shoal on August 10 and in Gibbs Shoal and Crab Hole on August 11. Prior to depositing shell on a mound, divers marked the center of each mound with a surface buoy attached to a weight. Immediately after deployment, divers inspected the mounds to ensure that shells were on top of the mound and spread the shell out so that the shell layer was $<5 \mathrm{~cm}$ in thickness. At Clam Shoal and Crab Hole, 2 additional mounds at each sanctuary, created in 2005 and 2006, were monitored to serve as a baseline for established reefs. Gibbs Shoal was first established as a sanctuary in 2009 and had no previously constructed mounds. A temperaturesalinity data logger was deployed on the top of 1 mound at each study sanctuary to measure environmental conditions. Temperature-salinity data were recorded every $30 \mathrm{~min}$ from June 2010 to September 2011, except when loggers malfunctioned (Fig. 2).

\section{Reef monitoring}

To quantify the success of oyster reef development on the reef mounds, we collected 2 sets of measurements: (1) abundance and size of oysters on deployed shell, and (2) oyster density on the surface of the marl boulders. Abundance of seed oysters and their size frequency were measured on 2 occasions in fall 2010 (October 7 to October 15) and 2011 (September 8 to September 13). Divers searched the mound top for deployed shell and retrieved 50 deployed shells or as many shells as could be located. Deployed shells could be distinguished from naturally recruited shells because deployed shells were larger and thicker. Retrieved shells were returned to the lab. We recorded the number of oysters on each shell and measured the $\mathrm{SH}$ of 5 haphazardly chosen oysters on each of the retrieved shells to obtain a size frequency for each mound.

We quantified the density and size of oysters on the marl mounds in each sanctuary during 3 samplings in fall 2010 and 2011 (same dates as shell sampling) and spring 2011 (May 25 to June 3). Divers haphazardly removed 2 marl pieces from both the top and bottom ( $<50 \mathrm{~cm}$ from the base) of the mound and immedi-

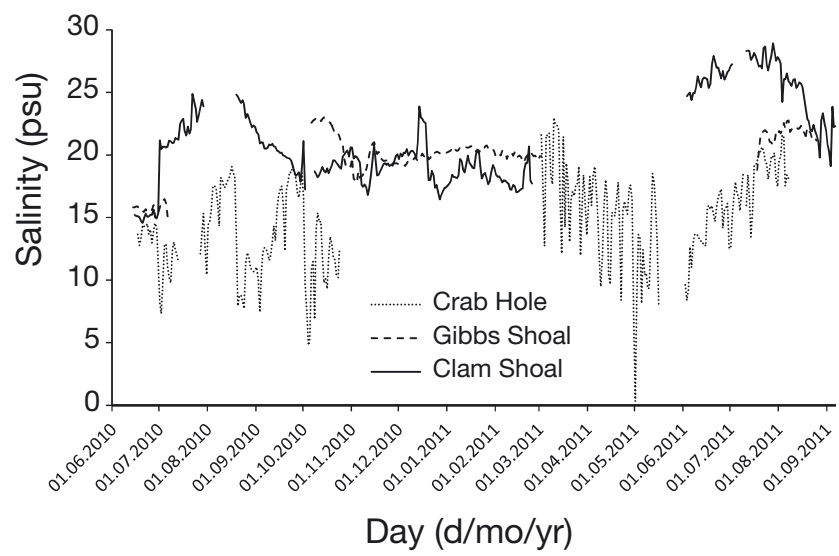

Fig. 2. Salinities (mean for each day) through time at the 3 experimental sanctuaries. Salinities were recorded every 30 min by a logger placed on the top of a mound 
ately placed the marl in separate plastic sacks. Care was taken to ensure that oysters remained attached to the marl or that any oysters that fell remained in the sack for quantification. Marl pieces were labeled with location on the mound (top or bottom) and mound type (early small seed, late small seed, large seed, shell, marl only, or old mound) and brought back to the lab for processing. Oyster size frequency was determined by measuring 50 haphazardly chosen oysters attached to the marl from both top and bottom samples of each mound. Oysters that recruit on the shells of existing oysters and small oysters can be difficult to find, especially on the highly complex 3-dimensional structure of oysters on marl. To ensure accurate counts, 3 different people counted the number of oysters on each marl piece. The 3-observer average abundance for each piece of marl was combined with the area of exposed marl to determine oyster density $\left(\mathrm{m}^{-2}\right)$. The surface area of the marl that was exposed on the mound and available for oysters to occupy was measured by orienting the marl as it was on the mound (oysters oriented vertically and on the side of marl with little or no epifauna on the bottom). The 'bird's eye view' area available for recruitment was determined by using a $5 \mathrm{~cm}$ grid quadrat held directly over the marl and recording the planar area that the marl occupied while looking straight down. This procedure was used instead of harvesting all oysters within a quadrat on the mound because of the difficulty in removing all oysters from pieces of marl in a defined area.

\section{NCDMF data}

To account for temporal variability in oyster recruitment in our study, we analyzed data from the NCDMF sanctuary program. We only analyzed data from sanctuaries that had mounds seeded and unseeded within 1 yr of their construction. This criterion was met 4 times. In 2006, South River had 14 mounds built in June and July, and 9 of the mounds were seeded in August. In 2008, South River had 8 mounds built in March, and 7 of the mounds were seeded in June. In 2008, West Bluff had 5 mounds built in June and July, and 3 of them were seeded in August. Finally, Ocracoke had 14 mounds built in September 2006, and 6 of these mounds were seeded in August 2007. In these instances, seed production and deployment were similar to methods described above, except 7001 (instead of 560 l) were added to each mound after seed reached $\sim 1 \mathrm{~cm}$ SH. These sanctuaries were sampled throughout the year, once a year starting in 2007, with sampling within a sanctuary being completed in $<1 \mathrm{wk}$. NCDMF sampling was similar to our methods, except 3 instead of 2 pieces of marl were collected from the top, middle (halfway between the crest and bottom), and bottom of the mound, for a total of 9 pieces of marl per mound. NCDMF's procedure for estimating oyster density $\left(\mathrm{m}^{-2}\right)$ differed from the method used in our study; they estimated surface area of the marl by measuring the length, width, and height of the marl and used $50 \%$ of the calculated surface area to determine the oysters per square meter. The abundance of oysters on each piece of marl was estimated by taking the sum of the total number of oysters counted within $10 \mathrm{~cm}$ increments of $\mathrm{SH}$.

\section{Statistical analysis}

Differences in salinity among sites were analyzed using a non-parametric Kruskal-Wallis test with site as the independent variable. The mean salinity per day (from measurements taken every $30 \mathrm{~min}$ ) was used as a replicate, and only days that had data from all sites were used. To determine whether large seed oysters were larger than small seed oysters before deployment, we ran a non-parametric Kruskal-Wallis test with oyster seed size as the dependent variable and treatment (early small, late small, and late large seed) as the independent variable. Non-parametric tests were necessary because data were non-normal and had heterogeneous variances. The numbers of oysters on shell or marl were not normally distributed and were heavily skewed toward 0, and a mixed effect-generalized linear mixed model (GLMM) was used to determine significant effects (R software, glmmADMB package using Laplace approximation). Independent fixed factors were shell and seed treatment (early shell, early small seed, late small seed, and late large seed), site, and sampling date. Shell and seed treatment included marl only (mounds with no shell addition) as a level when running analyses on oyster density on marl. Sampling date was a fixed factor and not a random factor because including temporal variation in recruitment was ecologically relevant. Mound was included as a random factor in all models. Model family (Poisson or negative binomial) and inclusion of factors and interactions were chosen based on lowest Akaike's information criterion (AIC) scores. Model creation started with treatment factor only, and then additional models were created by adding site and sampling date with and without interactions. The model with the lowest AIC 
was chosen. If this model had interactions that were not significant, the highest order interaction was removed to determine if the model could be improved (lower AIC). This was repeated until the best model was found. Model selection was performed separately with the following dependent variables: number of oysters per shell, oyster density $\left(\mathrm{m}^{-2}\right)$ on marl, and oyster density $\left(\mathrm{m}^{-2}\right)$ on marl from NCDMF-seeded sites. Depth was included as an additional factor in model selection for number of oysters per square meter on experimental mounds. Model selection for NCDMF data included an additional fixed factor, year created, and sampling date was referred to as age of mound. Size of oysters on shells was analyzed using a general linear model (GLMi R software, glme package with AIC) because it was a continuous variable with homogeneous variance (Bartlett's test; $\mathrm{p}>0.05$ ). Procedures for model selection were identical to those previously described.

To determine if seeding increased oyster abundance, which was difficult because the best models were complex with multiple interactions, separate tests were run for each sanctuary from the last sampling event with shell/seed treatment as the independent variable. The simplified models were run with the same GLMM procedure as previously described. The significant levels for these additional tests were adjusted to reduce Type I error when running multiple tests $(\mathrm{p}<0.012$; Bonferroni's correction).

\section{RESULTS}

Salinity was recorded for an average of $194 \mathrm{~d}$ at each sanctuary where we conducted our experiments (Fig. 2). All 3 sites only had $60 \mathrm{~d}$ of contemporaneous data. Crab Hole, Gibbs Shoal, and Clam Shoal experienced salinities (mean $\pm 1 \mathrm{SE}$ ) of $14.8 \pm$ $0.51,19.7 \pm 0.41$, and $21.2 \pm 0.64$, respectively, which were statistically different (Kruskal-Wallis chisquared $=57.52, \mathrm{df}=2, \mathrm{p}<0.001)$. Salinity at the 3 sanctuaries ranged from 0 to $32 \mathrm{psu}$, which spans the documented salinity of Pamlico Sound (Williams et al. 1973).

The $560 \mathrm{l}$ of shell deployed on each mound contained an average of 32000 seed oysters. We deployed $\sim 588000$ seed oysters to Pamlico Sound. On average, late large seed had the highest number of seed oysters per shell $(6.0 \pm 0.3$, mean $\pm \mathrm{SE})$, followed by early small seed $(4.4 \pm 0.6)$ and late small seed (2.9 \pm 0.2 ) before deployment (Fig. 3A). The sizes of large and small seed oysters on recycled adult shell were significantly different immediately before deployment (Kruskal-Wallis chi-squared $=662.78, \mathrm{df}=2$, $\mathrm{p}<0.001$; Fig. 4A).

The number of oysters per seeded shell was best described by a negative binomial model with shell and seed treatment, site, and date sampled as factors (see Table S1 in the Supplement at www.int-res.com/ articles/suppl/m480p119_supp.pdf for all models). Because of shells being overgrown by oysters or moved by wave action, only 1 shell originally deployed was found on the late large seed mounds in Gibbs Shoal during the second sampling, which negated producing a model with all interactions. The difficulty in finding shells after 2 summers of growth is evident in the total number found per 2 mounds, as shown in Fig. 3C. Most 2-way interactions were significant (Table S2 in the Supplement). The prevalence of significant interactions in our analysis leads us to offer tentative generalizations about main effects. Our comments about main effects, tempered by the relevant significant interaction effects, are offered as hypotheses rather than conclusions to clarify the confusing array of results. The shells deployed in June without seed or with small seed had more oysters than the shells deployed in August with small or large seed (Fig. 3, Table S2 in the Supplement). Post hoc comparisons were based on the models' standard errors around the mean not overlapping for the variables being compared. Crab Hole had more oysters on shells than the other 2 sites, and these differences were consistent across sampling dates. Additional models were run for each sanctuary separately with data from the fall 2011 sampling. In fall 2011, the shell and seed treatment was not significant ( $p>0.012$ ) when analyses were run for each site separately (Table S3 in the Supplement).

The size frequency of oysters on deployed shell was analyzed using a parametric model with shell and seed treatment and site as factors (Table S4 in the Supplement). The model would not run with year as a factor because of the lack of data for late large seed mounds at Gibbs Shoal during the second sampling. Shells deployed in June 2010 had larger oysters than shells deployed later, regardless of seed presence or deployment size of seed (Fig. 4, Table S5 in the Supplement). Shells deployed at Gibbs Shoal had larger oysters than shells deployed at Clam Shoal or Crab Hole. There were no significant interactions, but the inclusion of the interactions improved the model.

The density of oysters on marl was best described by a negative binomial model with site, depth, 


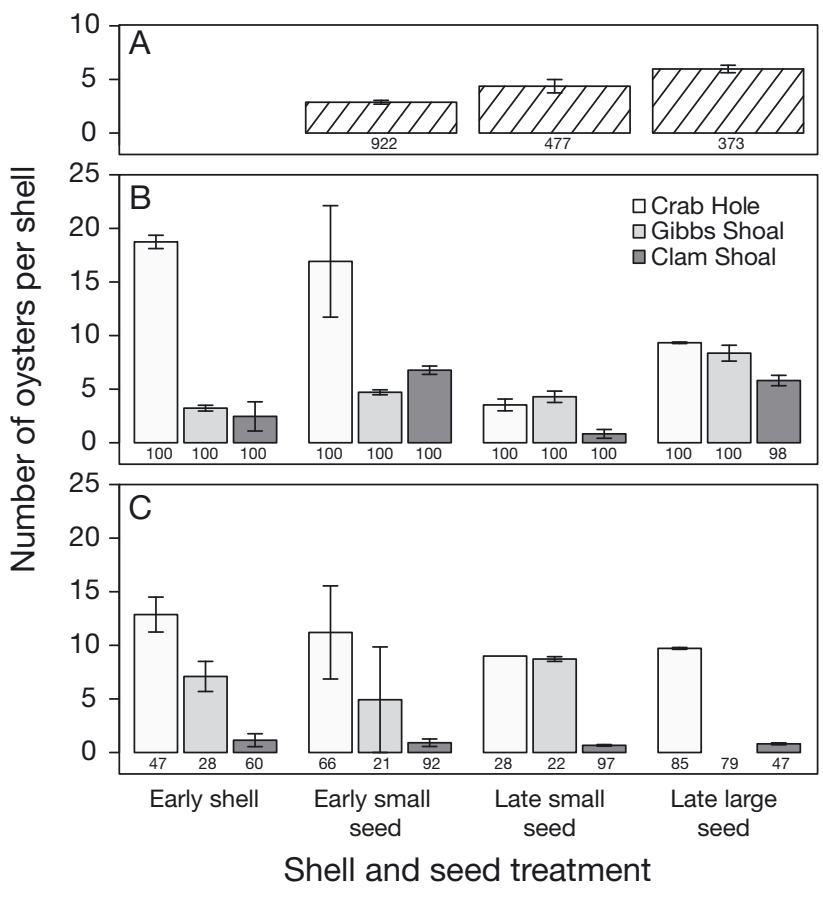

Fig. 3. Crassostrea virginica. Number of oysters per shell (mean $\pm 1 \mathrm{SE}$ ) (A) before shells were deployed in summer 2010, (B) after deployment in fall (October) 2010, and (C) the following year in September 2011. Number of shells sampled is noted above the $x$-axis

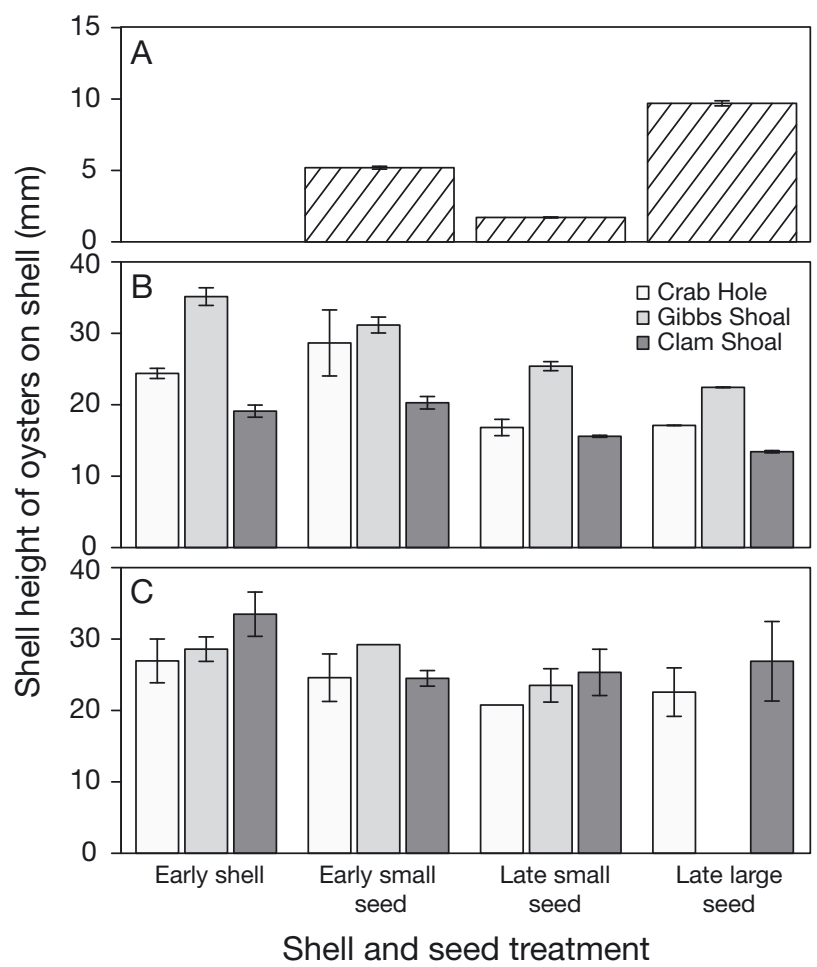

Fig. 4. Crassostrea virginica. Size of oysters (mean $\pm \mathrm{SE}$ ) per shell (A) before shells were deployed in summer 2010, (B) after deployment in fall (October) 2010, and (C) the following year in September 2011 and sampling date as factors with all interactions (Table S6 in the Supplement). Treatment was not included in the model because it did not explain a significant amount of the variation. Significant interactions resulted from the following: (1) oyster density at Gibbs Shoal increased through time, which was the opposite trend of the other 2 sites (Fig. 5, Table S7 in the Supplement); and (2) bottom marl had more oysters in the first 2 samplings, but mean oyster density was similar on the top and bottom of mounds at the final sampling (Fig. 6). The following trends among the main effects were evident: (1) the mean density of oysters on marl was 3 times greater at Clam Shoal than at the other 2 sites in the fall after deployment (Fig. 5, Table S7 in the Supplement); (2) oyster density at the bottom of the mound was greater than on the top of the mound; and (3) the third sampling in fall 2011 had fewer oysters than the samplings in fall 2010 and spring 2011. Because of the complexity of the overall model, separate models were run for each sanctuary at the fall 2011 sampling with shell and seed treatment as a fixed factor and mound as random factor. There was no difference in shell and seed treatments $(p>0.012)$ in any of the sanctuaries except for late large seed at Crab Hole, which had fewer oysters than marl only (Table S8 in the Supplement).

Our analysis of NCDMF data at 3 additional sanctuaries where mounds were both seeded and unseeded within $1 \mathrm{yr}$ of being created was limited because all 4 fixed factors (seeded or not, mound age, site, and year created) could not be included in 1 model due to inconsistent sampling of mounds each year. The best model included whether the mound was seeded, mound age, and site as factors (Table S9 in the Supplement). In general, seeded and unseeded mounts were not significantly different, and West Bluff had a higher density of oysters than the other 2 sites (Table S10 in the Supplement, Fig. 7).

\section{DISCUSSION}

The selected sanctuaries extended over the entire area of Pamlico Sound, and the temporal scale of results included 3 different years of reef creation. In the fall following experimental seeding, shells deployed without seed in June had as many oysters of equal or greater size as any of the shells deployed with seed. Our results indicate that seeding recently created artificial reefs is not necessary for successful restoration or enhanced oyster reef development in Pamlico Sound. 


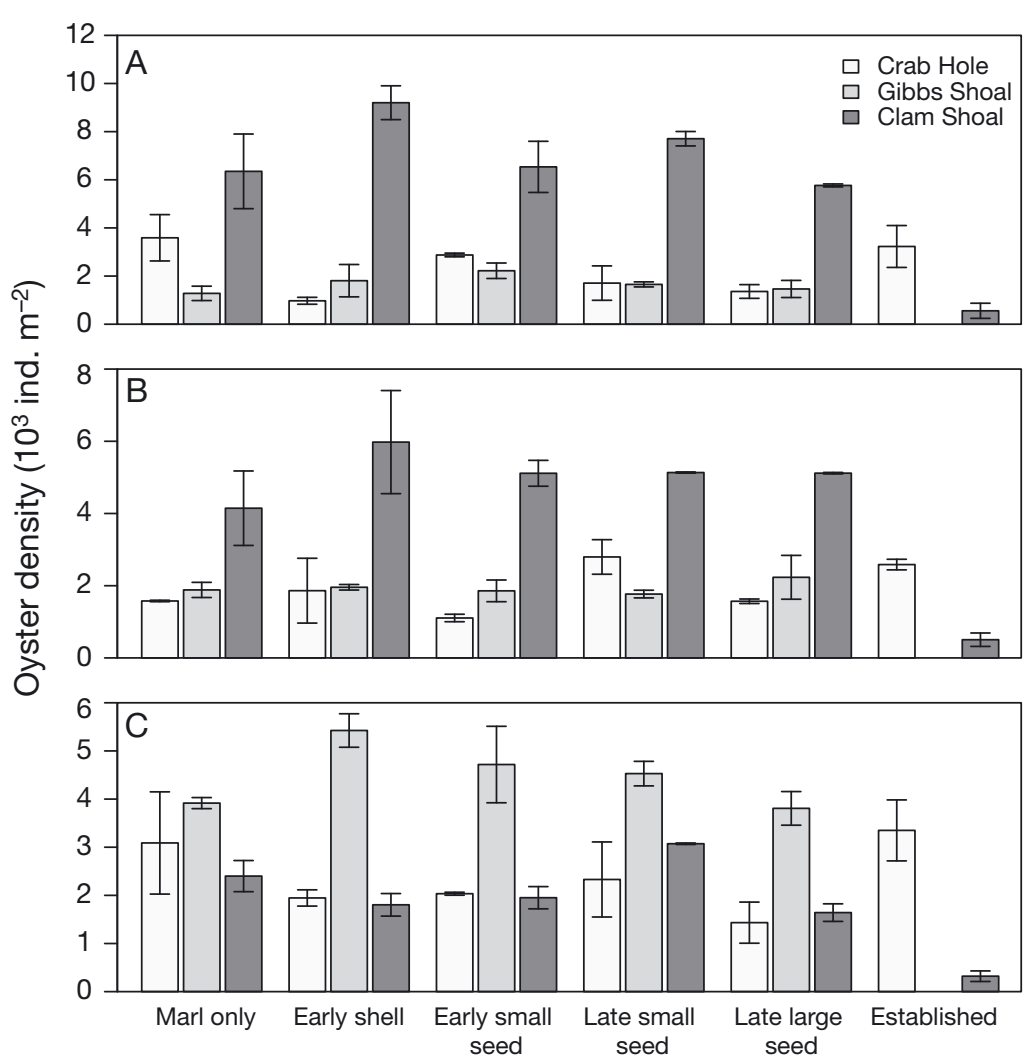

Fig. 5. Crassostrea virginica. Density of oysters (mean $\pm \mathrm{SE}$ ) on marl from the different shell and seed treatments in (A) fall 2010, (B) spring 2011, and (C) fall 2011. The density of oysters on mounds created in 2005 to 2006 were included in the figure as a baseline for successful restoration (Established) but were not included in the analysis

Seeding artificial reefs could have been expected to increase natural recruitment because oyster larvae are thought to be gregarious settlers (Kennedy et al. 1996). Laboratory experiments have found that the presence of seed oyster on shell (Hidu \& Haskin 1971, Keck et al. 1971) and the presence of chemical cues from adult conspecifics (Hidu et al. 1978, Turner et al. 1994, Tamburri et al. 2008) increase settlement of larvae. Oyster restoration monitoring in Chesapeake Bay also found positive relationships between adult oysters and spat (Southworth \& Mann 1998, Schulte et al. 2009). Although we did not directly measure settlement, natural oyster recruitment overwhelmed any benefit of seeding. Our results are not consistent with past findings because the presence of seed oysters did not increase recruitment on shell or on the mound substrate (marl). These discrepancies could result from seed oysters not producing a strong enough chemical cue to attract larvae, or the larvae could have been equally attracted to cues coming from biofilms on the marl, shell, and shell with seed (Tamburri et al. 1992, 2008).
Oyster recruitment and abundance varied within and among sites. Abundance of oysters on shell was highest at the low-salinity site, but oyster density was highest on marl at the high-salinity site. Greater recruitment in higher salinities has been found in Pamlico Sound (Ortega \& Sutherland 1992), Maryland (Beaven 1954), and the Gulf of Mexico (Butler 1954). The low recruitment to shell at the high-salinity site compared to the low-salinity site could have resulted from an earlier settlement pulse at the high-salinity site, with deployment of shell occurring after this pulse. Within sites, recruitment of oysters was higher at the bottom of the mounds than on the top at the first sampling. Lenihan (1999) monitored highand low-relief oyster reefs and also found higher oyster recruitment at deeper depths. But 1 yr after reef deployment, the density of oysters was similar between the top and bottom of the reef. In addition, oyster density decreased over time at the high-salinity site, remained relatively constant at the lowsalinity site, but increased at the midsalinity site. This could indicate that moderate salinities within Pamlico Sound may be the best areas for oyster restoration with the goal of maximizing oyster densities. However, the average density of oysters remained $>500$ oysters $\mathrm{m}^{-2}$ at all experimental sites, which is greater than the highest densities found on oyster reef sanctuaries throughout $\mathrm{NC}$ and is 50 times higher than the 10 oysters $\mathrm{m}^{-2}$ that has been used as an indicator for a functional reef (Powers et al. 2009).

The size of oysters on shell remained relatively constant, and sampling date was not included as a factor in the model of oyster size. Although we cannot determine the cause of relatively constant oyster size through time because we did not track individual oysters, we can infer causes from changes in abundance and size at different sites. Gibbs Shoal had larger oysters on shell than the other 2 sites, but the $\mathrm{SH}$ remained similar $1.5 \mathrm{yr}$ after deployment. This likely resulted from continued oyster recruitment with more small oysters during the second summer. Crab Hole had similar-sized oysters on shells during the second sampling probably because of overcrowding, and competition from high recruit- 


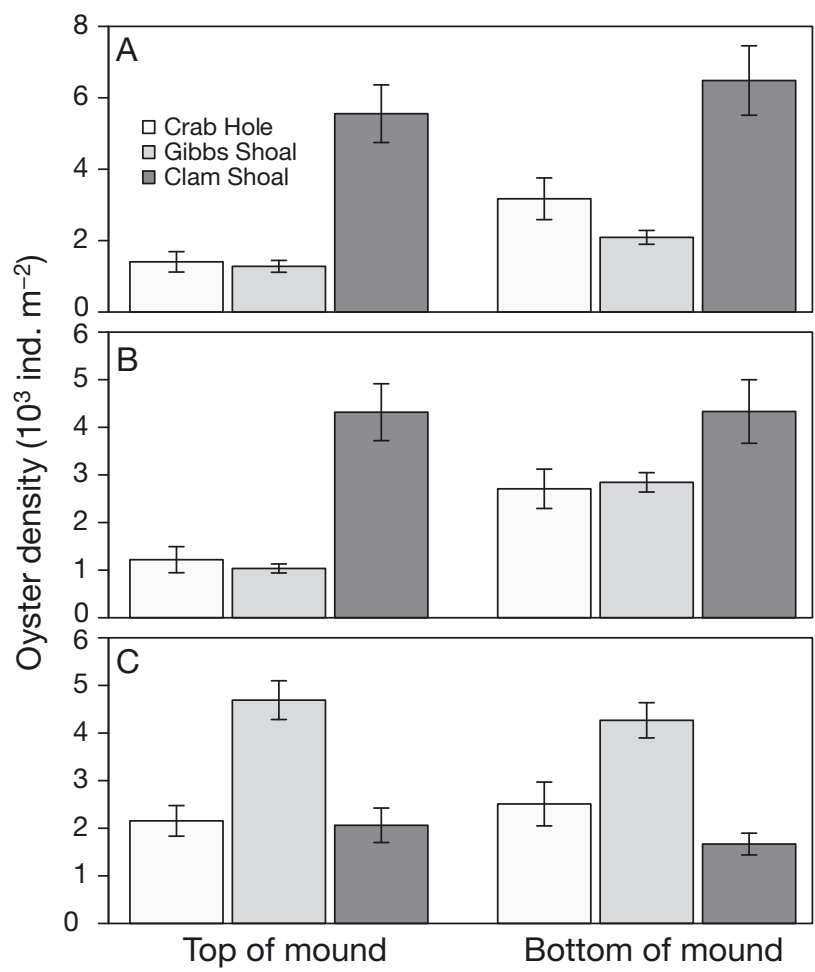

Fig. 6. Crassostrea virginica. Density of oysters (mean $\pm \mathrm{SE}$ ) on marl from the top and bottom of the mounds in (A) fall 2010, (B) spring 2011, and (C) fall 2011

ment during the first summer resulted in minimal growth. Finally, oysters on shell at Clam Shoal, on average, increased in size during the second sampling as compared to the first. This corresponded with low natural recruitment on the shells throughout the experiment. Further experiments must be conducted to determine the cause of minimal increases in mean oyster size.

Data from NCDMF support our experimental findings that seeding is neither necessary for nor beneficial to oyster restoration efforts in Pamlico Sound. At NCDMF-monitored sites, density of oysters on the marl varied between the $2 \mathrm{yr}$ that mounds were created. There was no difference in the density of oysters for seeded and unseeded mounds, confirming our conclusion that seeding does not increase the density of oysters on restored reefs.

In principle, addition of seed oysters could be advantageous for restoration efforts where oyster recruitment is limiting or mortality is high for recently settled oysters. These situations would exist if (1) populations are reduced low enough that gametes released by adults are not fertilized; (2) habitat is highly degraded (i.e. anoxia), and the existing oyster population has very low reproductive output; or (3)

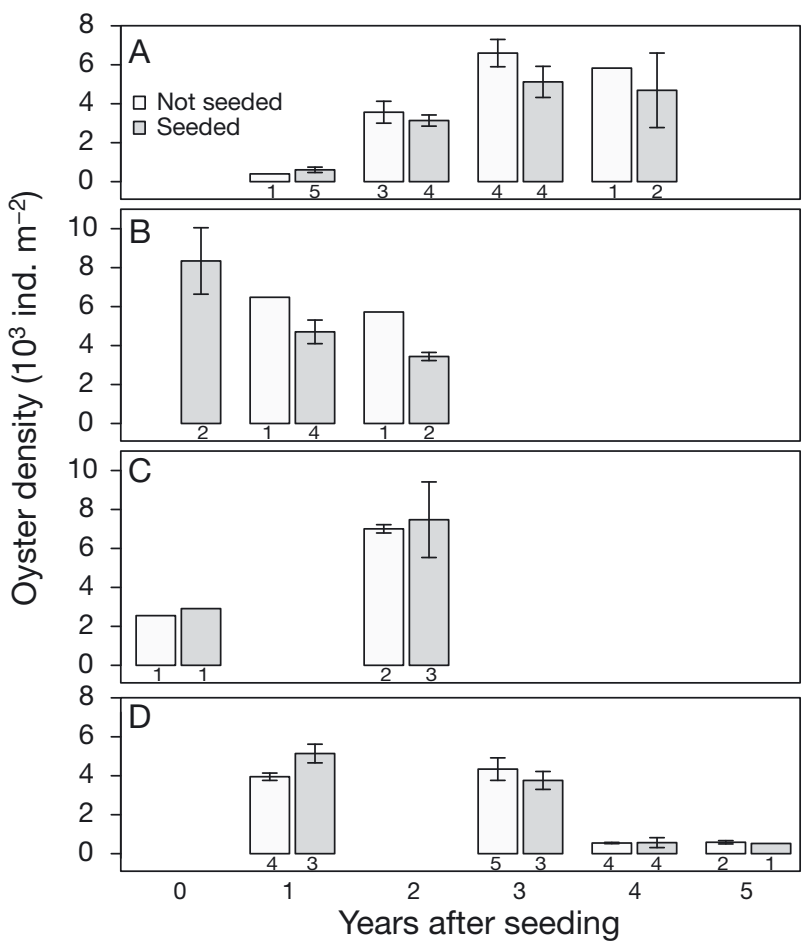

Fig. 7. Crassostrea virginica. Density of oysters (mean $\pm \mathrm{SE}$ ) on sampled marl from mounds seeded in (A) 2006 in South River, (B) 2008 in South River, (C) 2008 in West Bluff, and (D) 2006 in Ocracoke. Number of mounds sampled is noted above the $x$-axis

predators or disease cause high mortality of recently settled oysters. Although oyster recruitment varied, recruitment was not limiting because natural recruitment swamped any effect of seeded shell. Oyster predators (mud crabs, sheepshead, black drum, and oyster drills) exist throughout Pamlico Sound (Chesnut 1955, Rindone \& Eggleston 2011), but recruitment seemed to exceed the effect of predators, because the density of oysters remained above $500 \mathrm{~m}^{-2}$ regardless of shell/seed treatment.

Beck et al. (2011) estimated that oysters are only 5 to $10 \%$ of historic abundances in NC. However, our findings indicate that extant oyster populations in the areas surrounding the studied oyster sanctuaries have larval production sufficient to develop oyster reefs on deployed substrate, which is consistent with historical observations that oyster recruitment was not limiting south of Chesapeake Bay (Wallace 1952, Andrews 1954). Ortega \& Sutherland (1992) found that recruitment along the western side of Pamlico Sound seemed to be decreasing from 1988 to 1990, which they attributed to decreasing oyster populations. Our study 2 decades later did not find that recruitment was limiting. Moreover, no-harvest oyster sanctuaries throughout Pamlico Sound have 
remained viable for longer than $10 \mathrm{yr}$ (Powers et al. 2009), which would indicate that recruitment is not limiting, even if it is decreasing. Determining which factors contribute to the high recruitment in Pamlico Sound and why recruitment is low in other areas, such as Chesapeake Bay (Rodney \& Paynter 2006), is an important step to facilitate widespread oyster restoration.

Few experimental studies have tested the benefit of seeding restored oyster reefs, which is unexpected given the widespread use of seed oysters to restore and maintain oyster populations. One study on whether seed oysters augmented artificial reefs found $100 \%$ mortality of seed oysters from oyster drill predation in Mobile Bay, AL (Wallace et al. 2002). Although the benefit of seeding for oyster restoration will vary depending on where and when seeding is used, experiments are needed to determine if seeding is beneficial to oyster restoration.

Restoring habitats, whether because of widespread degradation or extirpation, is one of the great challenges of our century (Hobbs \& Harris 2001). Management restoration efforts are usually limited by management schemes that lead to unsustainable harvesting practices, the amount of money allocated for restoration, and the complexity of ecological processes. Managers and stakeholders should invest in experiments that test whether recruitment is limited before artificially augmenting natural recruitment, a strategy commonly used to restore other biogenic habitats such as seagrass meadows (Bell et al. 2008, Orth et al. 2012) and coral reefs (Clark \& Edwards 1995). As habitat restoration efforts increase, restoration techniques need to be firmly grounded in experimental ecology so that invested resources are maximized based on the spatial and temporal dynamics of recruitment and overall restoration goals.

Acknowledgements. This research was made possible by logistical support for seeding from NCDMF and the assistance of NCDMF employees C. Hardy, S. Slade, and C. Calhoon. We thank C. Lewis, M. Vozzo, L. Brown, L. Dee, W. Rogers, C. Martin, V. Pinkerton, M. McQuillan, C. Bland, J. Meiner, J. Moore, S. Vos, and C. Biddle for help with field research; J. Weiss for assistance with statistical analysis; and B. VanDusen, J. Fodrie, A. Anton, and 4 anonymous reviewers for improving drafts of the manuscript. This research was funded by a North Carolina Coastal Recreational Fishing License Grant. Partial funding for N.R.G was provided by the National Estuarine Research Reserve System under an award from the Estuarine Reserves Division, Office of Ocean and Coastal Resource Management, National Ocean Service, National Oceanic and Atmospheric Administration.

\section{LITERATURE CITED}

Abbe GR, Breitburg DL (1992) The influence of oyster toadfish (Opsanus tau) and crabs (Callinectes sapidus and Xanthidae) on survival of oyster (Crassostrea virginica) spat in Chesapeake Bay: Does spat protection always work? Aquaculture 107:21-31

Andrews JD (1954) Setting of oysters in Virginia. Proc Natl Shellfish Assoc 45:38-46

Associated Press (2007) Virginia commits \$2.1 million to oyster restoration. Chesapeake Bay J 30-31. www. bayjournal.com/article/virginia_commits_21_million_to_ oyster_restoration

Austin HM, Evans D, Haven DS (1996) A retrospective time series analysis of oyster, Crassostrea virginica, recruitment (1946-1993). J Shellfish Res 15:565-582

Beaven FG (1954) Various aspects of oyster seeding in Maryland. Proc Natl Shellfish Assoc 45:29-37

Beck MW, Brumbaugh RD, Airoldi L, Carranza A and 11 others (2011) Oyster reefs at risk and recommendations for conservation, restoration, and management. Bioscience 61:107-116

> Bell SS, Tewfik A, Hall MO, Fonseca MS (2008) Evaluation of seagrass planting and monitoring techniques: implications for assessing restoration success and habitat equivalency. Restor Ecol 16:407-416

Blankenship HL, Leber KM (1995) A responsible approach to marine stock enhancement. Am Fish Soc Symp 15:167-175

Brown K, George G, Peterson G, Thompson B, Cowan J (2008) Oyster predation by black drum varies spatially and seasonally. Estuar Coasts 31:597-604

Brumbaugh R, Coen L (2009) Contemporary approaches for small-scale oyster reef restoration to address substrate versus recruitment limitation: a review and comments relevant for the Olympia oyster, Ostrea lurida carpenter 1864. J Shellfish Res 28:147-161

Butler P (1954) Selective setting of oyster larvae on artificial cultch. Proc Natl Shellfish Assoc 45:95-109

Chesnut AF (1955) The distribution of oyster drills in North Carolina. Proc Natl Shellfish Assoc 46:134-139

Clark S, Edwards A (1995) Coral transplantation as an aid to reef rehabilitation: evaluation of a case study in the Maldive Islands. Coral Reefs 14:201-213

Coen LD, Luckenbach MW (2000) Developing success criteria and goals for evaluating oyster reef restoration: Ecological function or resource exploitation? Ecol Eng 15:323-343

> Coen LD, Brumbaugh RD, Bushek D, Grizzle R and others (2007) Ecosystem services related to oyster restoration. Mar Ecol Prog Ser 341:303-307

Grabowski JH (2004) Habitat complexity disrupts predatorprey interactions but not the trophic cascade on oyster reefs. Ecology 85:995-1004

Grabowski JH, Peterson C (2007) Restoring oyster reefs to recover ecosystem services. In: Cuddington $\mathrm{K}$, Byers JE, Wilson WG, Hastings A (eds) Ecosystem engineers: concepts, theory and applications. Elsevier-Academic Press, Amsterdam, p 281-298

Grizzle R, Burdick D, Greene J, Abeels H, Capone C (2006) Reef structure alternatives for restoration of oyster (Crassostrea virginica) populations in New Hampshire: a final report to the New Hampshire Estuaries Project. University of New Hampshire Marine Program, Jackson Estuarine Laboratory, Durham, NH

Hidu H, Haskin HH (1971) Setting of the American oyster 
related to environmental factors and larval behavior. Proc Natl Shellfish Assoc 61:35-50

Hidu H, Valleau WG, Veitch FP (1978) Gregarious setting in European and American oysters response to surface chemisty vs. waterborne pheromones. Proc Natl Shellfish Assoc 68:11-16

Hobbs RJ, Harris JA (2001) Restoration ecology: repairing the earth's ecosystems in the new millennium. Restor Ecol 9:239-246

Hobbs RJ, Hallett LM, Ehrlich PR, Mooney HA (2011) Intervention ecology: applying ecological science in the twenty-first century. Bioscience 61:442-450

Keck R, Maurer D, Kauer JC, Sheppard WA (1971) Chemical stimulants affecting larval settlement in the American oyster. Proc Natl Shellfish Assoc 61:24-28

Kennedy VS, College MSG, Newell RIE, Eble AF (1996) The eastern oyster: Crassostrea virginica. Maryland Sea Grant College, College Park, MD

Kennedy VS, Breitburg DL, Christman MC, Luckenbach MW and 6 others (2011) Lessons learned from efforts to restore oyster populations in Maryland and Virginia, 1990 to 2007. J Shellfish Res 30:719-731

Kraeuter J, Ford S, Canzonier W (2003) Increased biomass yield from Delaware Bay oysters (Crassostrea virginica) by alternation of planting season. J Shellfish Res 22:39-49

Kulp RE, Politano V, Lane HA, Lombardi SA, Paynter KT (2011) Predation of juvenile Crassostrea virginica by two species of mud crabs found in the Chesapeake Bay. J Shellfish Res 30:261-266

Lenihan HS (1999) Physical-biological coupling on oyster reefs: how habitat structure influences individual performance. Ecol Monogr 69:251-275

Lenihan HS, Peterson CH, Byers JE, Grabowski JH, Thayer GW, Colby DR (2001) Cascading of habitat degradation: oyster reefs invaded by refugee fishes escaping stress. Ecol Appl 11:764-782

Lotze HK, Lenihan HS, Bourque BJ, Bradbury RH and 6 others (2006) Depletion, degradation, and recovery potential of estuaries and coastal seas. Science 312:1806-1809

Mann R, Powell E (2007) Why oyster restoration goals in the Chesapeake Bay are not and probably cannot be achieved. J Shellfish Res 26:905-917

> McDonald J (1982) Divergent life-history patterns in the cooccurring intertidal crabs Panopeus herbstii and Eurypanopeus depressus (Crustacea: Brachyura: Xanthidae). Mar Ecol Prog Ser 8:173-180

Michener WK, Kenny PD (1991) Spatial and temporal patterns of Crassostrea virginica (Gmelin) recruitment: relationship to scale and substratum. J Exp Mar Biol Ecol 154:97-121

> Newell R, Alspach G, Kennedy V, Jacobs D (2000) Mortality of newly metamorphosed eastern oysters (Crassostrea virginica) in mesohaline Chesapeake Bay. Mar Biol 136: 665-676

Ortega S, Sutherland J (1992) Recruitment and growth of the eastern oyster, Crassostrea virginica, in North Carolina. Estuaries 15:158-170

Editorial responsibility: Romuald Lipcius, Gloucester Point, Virginia, USA
Orth RJ, Moore KA, Marion SR, Wilcox DJ, Parrish DB (2012) Seed addition facilitates eelgrass recovery in a coastal bay system. Mar Ecol Prog Ser 448:177-195

Peterson C, Summerson H, Huber J (1995) Replenishment of hard clam stocks using hatchery seed: combined importance of bottom type, seed size, planting season, and density. J Shellfish Res 14:293-300

Peterson CH, Grabowski JH, Powers SP (2003) Estimated enhancement of fish production resulting from restoring oyster reef habitat: quantitative valuation. Mar Ecol Prog Ser 264:249-264

> Piehler MF, Smyth AR (2011) Habitat-specific distinctions in estuarine denitrification affect both ecosystem function and services. Ecosphere 2:art12

> Powers SP, Peterson CH, Grabowski JH, Lenihan HS (2009) Success of constructed oyster reefs in no-harvest sanctuaries: implications for restoration. Mar Ecol Prog Ser 389: 159-170

Rindone RR, Eggleston DB (2011) Predator-prey dynamics between recently established stone crabs (Menippe spp.) and oyster prey (Crassostrea virginica). J Exp Mar Biol Ecol 407:216-225

> Rodney WS, Paynter KT (2006) Comparisons of macrofaunal assemblages on restored and non-restored oyster reefs in mesohaline regions of Chesapeake Bay in Maryland. J Exp Mar Biol Ecol 335:39-51

> Schulte DM, Burke RP, Lipcius RN (2009) Unprecedented restoration of a native oyster metapopulation. Science 325:1124-1128

Soniat T, Broadhirst BC, Haywood EL (1991) Alternatives to clamshell as cultch for oysters and the use of gypsum for the production of cultchless oysters. J Shellfish Res 10: 405-410

Southworth M, Mann R (1998) Oyster reef broodstock enhancement in the Great Wicomico River, Virginia. J Shellfish Res 17:1101-1114

Tamburri M, Zimmerfaust R, Tamplin M (1992) Natural sources and properties of chemical inducers mediating settlement. Biol Bull 183:327-338

Tamburri MN, Luckenbach MW, Breitburg DL, Bonniwell SM (2008) Settlement of Crassostrea ariakensis larvae: effects of substrate, biofilms, sediment and adult chemical cues. J Shellfish Res 27:601-608

Turner E, Zimmerfaust R, Palmer M, Luckenbach M, Pentcheff N (1994) Settlement of oyster (Crassostrea virginica) larvae effects of water-flow and a water-soluble chemical cue. Limnol Oceanogr 39:1579-1593

Wallace DH (1952) A critique of present biological research on oysters. Proc Gulf Caribb Fish Inst 5:132-136

Wallace RK, Rikard FS, Howe JC (2002) Optimum size for planting hatchery produced oyster seed. Sea Grant Final Tech Rpt, Grant No. NA86RG0073, Project No. R/LR-46NSI-2 www.masgc.org/pdf/masgp/01-027.pdf

Williams AB, Posner GS, Woods WJ, Deubler EE (1973) A hydrographic atlas of larger North Carolina sounds. Univ of North Carolina Sea Grant Publ UNC-SG-73-02. UNC Sea Grant College Program, Raleigh, NC

Submitted: July 18, 2012; Accepted: November 19, 2012

Proofs received from author(s): March 18, 2013 